Racic 6 (2) (2021)
JUIVERSITAS
ABDURRAB

\title{
PERENCANAAN RUTE JARINGAN LINTAS ANGKUTAN BARANG DI KOTA PEKANBARU DENGAN APLIKASI PTV VISUM
}

\author{
Rahmat Tisnawan ${ }^{1}$, Fitra Ramdhani², Muhammad Rifky Ariansyah ${ }^{3}$ \\ Program Studi Teknik Sipil Fakultas Teknik Universitas Abdurrab \\ Jl. Riau Ujung No. 73 Pekanbaru Riau \\ Telp (0761) 38762 \\ rahmat.tisnawan@univrab.ac.id
}

\begin{abstract}
Info Artikel Abstrak
Sejarah Artikel:

Diterima : Desember 2021 Disetujui : Desember 2021 Dipublikasikan : Des 2021

Keywords:

Angkutan Barang, Jaringan Lintas Angkutan Barang, Pembebanan

Penurunan performa ruas ruas-ruas jalan di Kota Pekanbaru terjadi akibat peningkatan pergerakan angkutan barang yang tidak diimbangi dengan perkembangan operasi fasilitas angkutan barang yang baik sehingga terjadi ketidakteraturan lalu lintas. Maka diperlukan penyiapan fasilitas operasi angkutan barang yang lebih efektif dan efisien. Skenario penanganan yang diterapkan adalah dengan pengaturan jaringan lintas dan peningkatan kapasitas ruas - ruas jalan yang dilintasi angkutan barang untuk meningkatkan performa ruas jalan. Pembebanan terhadap tiap - tiap skenario penanganan, termasuk pada tahun rencana 2030 dilakukan untuk mengetahui performa ruas jalan. Skenario pembangunan jalan lingkar dan jaringan lintas angkutan barang merupakan pilihan yang meningkatkan performa ruas jalan, dimana pada tahun dasar kecepatannya $33,43 \mathrm{~km} / \mathrm{jam}$ menjadi 40,25 km/jam pada tahun 2025 dan pada tahun 2030 kecepatannya menjadi 39,41 $\mathrm{km} / \mathrm{jam}$
\end{abstract}

Kata Kunci: Angkutan Barang, Jaringan Lintas Angkutan Barang, Pembebanan 


\section{PENDAHULUAN}

Kota Pekanbaru menjadi pusat tujuan dari daerah lain untuk mendistribusikan barang, dengan pergerakan angkutan barang dari zona eksternal ke zona internal dengan persentase sebesar $44 \%$. Pergerakan dari zona internal ke zona eksternal dengan persentase sebesar 39\%, menandakan bahwa Kota Pekanbaru juga sebagai pusat pendistribusian barang ke wilayahwilayah lain. Hal ini disebabkan karena letak Kota Pekanbaru yang strategis, yaitu diantara dengan Kabupaten Kampar, Kabupaten Pelalaan dan Kabupaten Siak.

Dengan pertumbuhan penduduk sebesar 2,49\% per tahun dan pertumbuhan Produk Domestik Regional Bruto (PDRB) sebesar 6,10\% per tahun, Kota Pekanbaru akan mengalami peningkatan permintaan konsumsi masyarakat dan akan berpengaruh terhadap peningkatan pergerakan angkutan barang yang disebabkan oleh proses distribusi. Selain itu, rata-rata pertumbuhan kendaraan di Kota Pekanbaru adalah sebesar 4,0\% per tahun dapat menambah beban volume pada ruas jalan. Angkutan barang yang beroperasi sebagian besar adalah pikap, truk sedang 2 sumbu, hingga truk besar 3 sumbu bisa memasuki Kota Pekanbaru.

Diketahui bahwa ruas jalan dengan V/C rasio 0,85 - 1 (Sumber Dishub Kota Pekanbaru) yaitu seperti Jalan Garuda Sakti, Jalan Kaharuddin Nasution, Jalan Kubang Raya, Jalan Siak, Jalan Sudirman, Jalan Riau Ujung, Jalan Riau, Jalan Sukarno Hatta, Jalan Yos Sudarso, Jalan HR. Soebrantas, Jalan Imam Munandar, Jalan Hangtuah, Jalan Tuanku Tambusai, Jalan Lintas Petapaha, Jalan Paus, Jalan Ir. H. Juanda, Jalan Durian, dan Jalan Darma Bakti. Ruas jalan dengan V/C rasio 0,75 - 0,84 (Sumber Dishub Kota Pekanbaru) yaitu Jalan Garuda Sakti 2, Jalan Garuda Sakti 3, Jalan Siak II 4, Jalan Siak, dan sebagainya. Dengan bertambahnya volume lalu lintas pada ruas jalan tersebut maka akan menperburuk nilai V/C rasio. Oleh karena itu diperlukan persiapan lintasan yang bisa mengakomodasi pergerakan angkutan barang di Kota Pekanbaru sebagai langkah antisipasi terhadap perkembangan angkutan barang yang akan menurunkan performa lalu lintas,

\section{TINJAUAN PUSTAKA}

Permodelan Jaringan Lintas Angkutan Barang 


\section{Bangkitan Perjalanan Angkutan Barang}

Untuk merencanakan jaringan lintas angkutan barang diperlukan Matrik Asal - Tujuan Barang. Pada tahap bangkitan perjalanan ini bertujuan untuk mengetahui perjalanan angkutan barang antar zona, selain itu Matrik Asal - Tujuan ini dipergunakan untuk meramalkan besarnya bangkitan pada tahun rencana.

\section{Distribusi Perjalanan Angkutan Barang}

Distribusi perjalanan merupakan tahap kedua dari empat tahapan perencanaan pemodelan transportasi. Hubungan interaksi antar sejumlah zona dipertimbangkan berdasarkan bangkitan dan tarikan perjalanan pada tahap sebelumnya. Konsep dasar distribusi perjalanan adalah volume perjalanan orang antar zona diestimasikan berdasarkan daya tarik dari zona, kendala antar zona dan produksi perjalanan dari tiap zona. Kendala antar zona untuk tahun rencana diperkirakan didapat dari spesifikasi rencana transportasi, antara lain adalah biaya perjalanan, waktu, dan jarak.

Beberapa model analisis sebaran perjalanan antara lain :

a. Model Konvensional

Metode tidak langsung dan metode langsung merupakan bagian dari metode ini. Data survey tujuan, seperti pencatatan nomor kendaraan, wawancara di tepi jalan digunakan untuk pengembangan model ini. Matrik Asal Tujuan merupakan hasil dari proses survey.

b. Model Analogi

Asumsi model ini berdasarkan bahwa Matrik Asal Tujuan di masa depan merupakan fungsi dari Matrik Asal Tujuan pada saat ini dikali dengan faktor pertumbuhan. Persamaan matematisnya sebagai berikut :

$\mathbf{T}_{\text {id }}=\mathbf{t}_{\text {id }} \mathbf{x} \mathbf{E}$

Keterangan

$\mathrm{T}_{\mathrm{id}}=\quad$ Pergerakan pada masa depan dari zona asal (i) ke zona tujuan (d)

$t_{i d}=\quad$ Pergerakan pada saat ini dari zona asal (i) ke zona tujuan (d)

$\mathrm{E}=\quad$ Tingkat pertumbuhan

Tiga kelompok utama model analogi yaitu: metode seragam (tanpa batasan), metode batasan-tarikan atau batasan-bangkitan (dengan satu batasan) dan metode dua batasan (metode fratar, metode rata-rata, metode furness, metode Detroit).

c. Model Sintesis

Pergerakan zona asal ke zona tujuan berbanding terbalik dengan jarak kedua zona dan berbanding lurus dengan besarnya bangkitan lalu lintas dizona tujuan merupakan prinsip 
yang mendasari model ini. Fenomena sebaran perjalanan model sistesis dianalogikan dengan hukum Gravitasi Newton yang menganggap distribusi perjalanan antara zona asal dan zona tujuan berbanding lurus dengan jumlah bangkitan dan tarikan serta berbanding terbalik kuadratis terhadap biaya perjalanan atau fungsi hambatan antara kedua zona tersebut.

Untuk penganalisaan pada penelitian ini menggunakan faktor pertumbuhan dengan Metode Detroit. Pada metode ini diasumsikan, jika meningkat jumlah pergerakan dari zona asal $\boldsymbol{i}$ sesuai dengan tingkat pertumbuhan $\boldsymbol{E} \boldsymbol{i}$, disebarkan juga pergerakannya ke zona $\boldsymbol{d}$ sebanding dengan $\boldsymbol{E} \boldsymbol{d}$ dibagi dengan tingkat pertumbuhan global (E), dengan persamaan sebagai berikut:

$$
T_{\text {id }}=\frac{t_{d d} \cdot E_{i} \cdot E_{d}}{E}
$$

\section{Proporsi Penggunaan Angkutan Barang}

Mengkalibrasi pemilihan model moda pada tahun dasar dengan mengetahui peubah bebas yang mempengaruhinya merupakan maksud dari proses ini. Tamin, O.Z. (2008) menyatakan bahwa tahap yang berbeda-beda dalam proses perencanaan dan pemodelan transportasi dapat untuk menganalisa pemilihan moda transportasi.

Pemilihan moda tersebut nantinya akan dipakai untuk melakukan pembebanan perjalanan pada setiap ruas. Pembebanan perjalanan dilakukan dengan cara merubah satuan perjalanan orang per hari menjadi satuan kendaraan per hari, dengan rumus sebagai berikut:

$$
\text { Trip }-\mathbf{i}=\{(\text { Trip } \times \% M S-i) /(\text { Lf } \times \text { Kap }-\mathbf{i})\} \times \% \text { jam sibuk }
$$

\section{Keterangan :}

$\begin{array}{ll}\text { Trip }-\mathrm{i} & =\text { Besaran perjalanan dari zona A ke zona T (kend/jam) } \\ \text { Trip } & =\text { Besaran perjalanan dari zona A ke zona T (orang/hari) } \\ \% \mathrm{MS}-\mathrm{i} & =\text { Prosentase pemilihan moda } \\ \mathrm{Lf}-\mathrm{i} & =\text { Faktor muat } \\ \text { Kap }-\mathrm{i} & =\text { Kapasitas kendaraan } \\ \% \text { jam sibuk } & =\text { Prosentase jam sibuk }\end{array}$

\section{Pembebanan Perjalanan}

Ortuzuar, J. De. And Willumsen, L.G. (1990) menyatakan bahwa tahapan terakhir dari proses pemodelan transportasi adalah pembebanan perjalanan yang terbagi diantara bebarapa zona oleh moda perjalanan dan dengan hasil dari arus jaringan transportasi. Untuk melakukan 
proses pembebanan diperlukan data seperti matrik asal dan tujuan perjalanan, kapasitas jalan dan karakteristik jaringan. Matrik yang dipakai pada ruas jalan merupakan matrik yang telah dijadikan satuan smp (satuan mobil penumpang) per jam. Luaran dari proses ini yaitu arus kendaraan tiap ruas atau biaya dan waktu tempuh perjalanan

Proses pembebanan ini bertujuan untuk :

a. Mengestimasi volume lalu lintas pada ruas-ruas jalan di persimpanagn dan dalam jaringan jalan bila memungkinkan

b. Memperoleh estimasi biaya perjalanan antara tujuan perjalanan dan asal perjalanan yang dipakai pada model pemilihan moda dan distribusi angkutan perjalanan

\section{Validasi Model Jaringan Jalan}

Setelah model jaringan terbentuk lengkap dengan pembebanan pada ruas, melakukan validasi model adalah langkah selanjutnya, yaitu membandingkan dan menilai kesesuaian hasil volume lalu lintas pada ruas jalan hasil survei dengan volume lalu lintas hasil model. Apabila tingkat validasinya maksimal $20 \%$ dai survey maka hasil model dapat diterima, bila lebih dari $20 \%$ maka model yang telah dibuat diperbaiki kembali.

Uji statistik Chi-Square $\left(\mathrm{X}^{2}\right)$ dilakuan sebelum melakukan validasi, Uji statistik ini digunakan untuk mengetahui hasil simulasi yang dihasilkan mempunyai perbedaan yang cukup signifikan atau tidak. Validasi tidak diperlukan lagi bila hasil simulasi diterima yaitu tidak ada perbedaan yang signifikan. Uji statisktik hasil simulasi dilakukan berdasarkan hasil Chi-square test antara mean hasil simulasi dengan mean hasil observasi. Harinaldi (2005), menyatakan persamaan Chi-square adalah sebagai sebagai berikut :

$$
\sum_{i=1}^{k}\left[\frac{(O i-E i)^{2}}{E i}\right]
$$

Sumber : Prinsip-prinsip Statistik untuk Teknik dan Sains, 2005

Keterangan :

$\mathrm{X}^{2} \quad=$ Chi-square

Oi = data hasil observasi

$\mathrm{Ei}=$ data hasil model

\section{Analisis pada Tahun Rencana}

Peramalan yang dilakukan untuk bangkitan dan tarikan tiap zona lalu lintas pada tahun target didapat melalui persamaan :

$\mathbf{P t}=\mathbf{P o}(\mathbf{i}+\mathbf{1})^{\mathbf{n}}$ 
Keterangan :

$\mathrm{Pt}=$ besarnya nilai variabel $\mathrm{X}$ pada tahun $\mathrm{ke}-\mathrm{n}$

Po $=$ besarnya nilai variabel pada tahun sekarang

$\mathrm{I}=$ tingkat pertumbuhan rata - rata

$\mathrm{n}=$ rentang waktu tahun analisis

\section{METODE}

Tahapan penelitian terdiri dari 4 tahap, yaitu:

1. Tahap Persiapan

Proses dalam tahapan ini diantaranya proses pengamatan kondisi lapangan dan pengidentifikasian masalah yang terdapat di wilayah studi. Setelah didapatkan masalah yang ada, selanjutnya beberapa permasalahan diambil untuk dirumuskan.

2. Tahap Pengumpulan Data

Pada tahapan ini dilakukan pengambilan data primer dan data sekunder. Survey terkait dengan kondisi lapangan dilakukan untuk mendapatkan data primer, sedangkan data sekunder di dapat dari instansi terkait.

3. Tahap pengolahan dan analisis data

Penelitian kuantitatif menggunakan statistik untuk menganalisa data. Teknik statistik deskriptif digunakan untuk menganalisis data dalam penelitian ini. Tahapan menganalisis data sebagai berikut:

Analisis Model Lalu Lintas Saat Ini (Tahun Dasar)

Pembebanan lalu lintas dilakukan untuk menganalisis kondisi lalu lintas pada kondisi dasar. Analisa pembebanan lalu lintas dilakukan Untuk mengetahui jumlah beban pada ruas jalan dan simpang dilakukan analisis pembebanan lalu lintas. PTV Visum digunakan sebagai software untuk Model pembebanan.

Data - data yang telah dikumpulkan selanjutnya digunakan untuk menganalisis performa lalulintas maupun sistemnya yang dibantu dengan paket software Visum Versi 10.0. Untuk melakukan pembebanan dengan Software Visum diperlukan langkah-langkah sebagai berikut.

Data yang telah dihimpun, kemudian dilakukan modifikasi, distrukturisasi, serta dibentuk sesuai dengan format yang sudah ditentukan oleh software VISUM. Dalam pengembangan jaringan (network), diperlukan data-data mengenai zona, node dan ruas jalan (link) yaitu sebagai berikut : 
1) Pembagian zona lalu lintas

2) Lokasi dan kodefikasi node (simpul)

3) Kondisi ruas jalan (link)

4) Input data

5) Proses dan Keluaran

6) Validasi Model Jaringan Jalan

7) Evaluasi Penanganan (Do Something)

8) Analisis Penanganan pada Tahun Dasar

9) Analisis pada Tahun Rencana

10) Analisis Penanganan pada Tahun Rencana

11) Evaluasi Usulan Skenario pada Tahun Rencana

12) Rekomendasi

4. Tahap Kesimpulan

Kesimpulan didapat setelah dilakukan analisa dari pengolahan data yang didapat.

\section{HASIL DAN PEMBAHASAN}

\section{Analisis Rencana Jaringan Lintas Angkutan Barang}

\section{Perencanaan Rute}

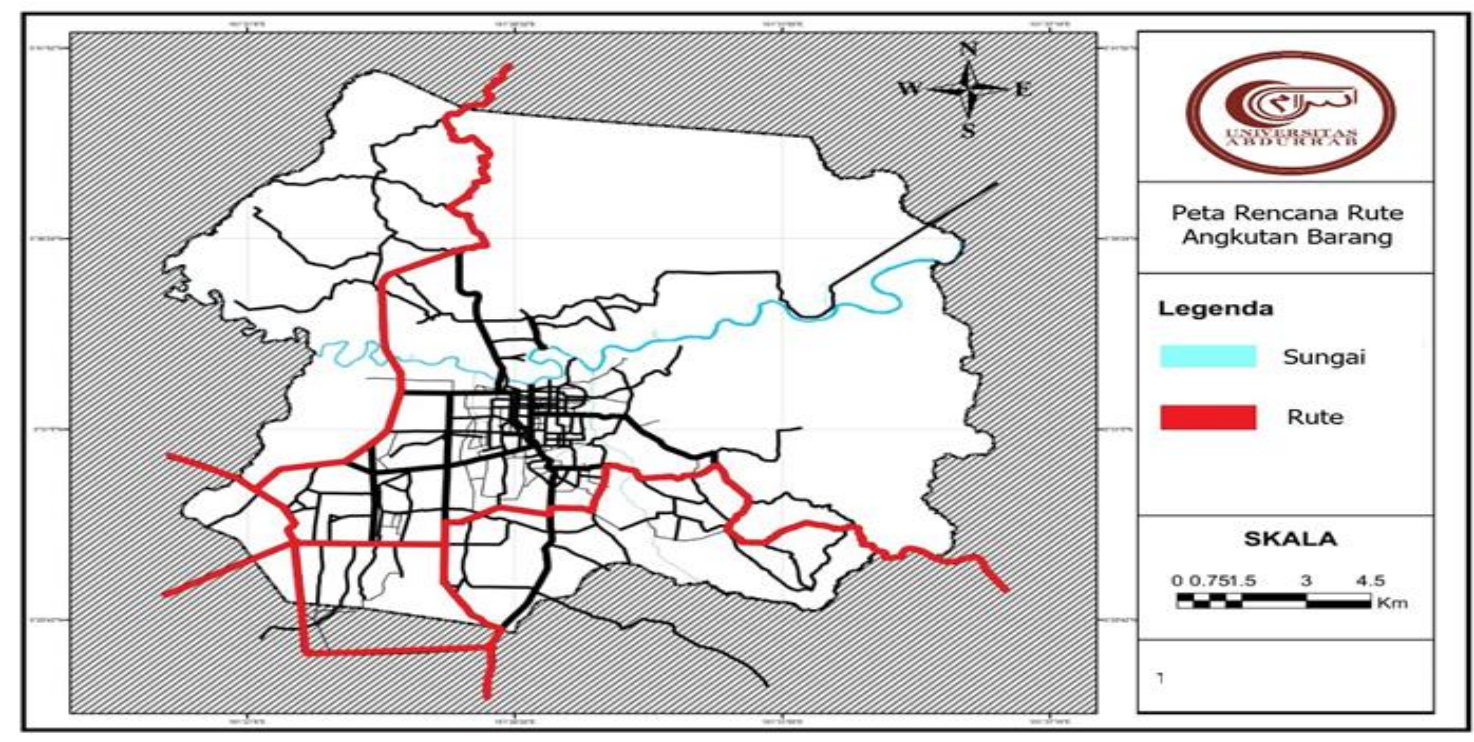

Gambar 1. Peta Rencana Penetapan Rute Angkutan Barang

Ruas jalan yang akan dilalui angkutan barang harus sudah sesuai untuk dilalui kendaraan angkutan barang yang diatur dalam PP Nomor 55 Tahun 2012 Tentang Kendaraan dan Undang- 
Undang Nomor 22 Tahun 2009 Tentang Lalu Lintas Angkutan Jalan, dimana kendaraan dengan dimensi terbesar dapat melintasi ruas jalan tersebut, dan perlu tambahan rambu dan RPPJ mengenai jaringan lintas angkutan barang. Berikut adalah jalan yang sudah sesuai : Jalan Air Hitam, Jalan Arifin Achmad, Jalan Datuk Setia Maharaja, Jalan Garuda Sakti, Jalan Hang Tuah, Jalan HR Soebrantas, Jalan Imam Munandar, Jalan Kelapa Sawit - Rawamangun, Jalan Kubang Raya, Jalan Rawamangun, Jalan Raya Pekanbaru - Sungai Pagar, Jalan Siak II, Jalan Soekarno Hatta, Jalan Yos Sudarso, Jalan Lintas Petapahan - Garuda Sakti

\section{Pembebanan Lalu Lintas}

\section{Peramalan kondisi performa jaringan jalan tahun 2025 dan 2030}

Peramalan untuk tahun 2025 dan 2030 pada jaringan lintas angkutan barang maka data jumlah kendaraan 5 tahun terakhir diperlukan untuk mengetahui tingkat pertumbuhan kendaran. Didapat untuk Kota Pekanbaru tingkat pertumbuhan nya sebesar 2,2 \%.

Analisa dilakukan dengan melakukan beberapa skenario sebagai berikut :

1. Analisis Rencana Skenario Jaringan Lintas Alternatif 1, Do Nothing tanpa adanya jalur lalu lintas angkutan barang (JLAB)

2. Analisis Rencana Skenario Jaringan Lintas Alternatif 2, Do Something adanya JLAB

3. Analisis Rencana Skenario Jaringan Lintas Alternatif 3, Do Something adanya JLAB dan Jalan Lngkar

4. Analisis Rencana Skenario Jaringan Lintas Alternatif 4, Do Something adanya JLAB dan Jalan Lingkar serta Pelebaran Jalan

Berikut adalah perbandingan dari performa jaringan jalan baik tanpa atau dengan JLAB dan pembangunan jalan lingkar yang dilakukan pada tahun rencana 2025.

Tabel. 1 Perbandingan Performa Jalan di Kota Pekanbaru 2025

\begin{tabular}{|c|c|c|c|c|c|c|}
\hline \multirow[b]{2}{*}{ No } & \multirow[b]{2}{*}{ Indikator } & \multicolumn{5}{|c|}{ Perbandingan performa jalan } \\
\hline & & $\begin{array}{c}\text { Do } \\
\text { nothing }\end{array}$ & $\begin{array}{c}\text { Do } \\
\text { something } \\
\text { Alternatif } \\
1 \\
\end{array}$ & $\begin{array}{c}\text { Do } \\
\text { something } \\
\text { Alternatif } \\
2 \\
\end{array}$ & $\begin{array}{c}\text { Do } \\
\text { something } \\
\text { Alternatif } \\
3 \\
\end{array}$ & $\begin{array}{c}\text { Do } \\
\text { something } \\
\text { Alternatif } \\
4 \\
\end{array}$ \\
\hline 1 & Kecepatan (km/jam) & 31,92 & 40,02 & 42,11 & 40,52 & 42,33 \\
\hline 2 & Volume rata-rata (smp/jam) & 2218 & 936 & 904 & 959 & 934 \\
\hline 3 & Waktu tempuh rata-rata (jam) & $1^{0} 56^{\prime} 53^{\prime \prime}$ & $1^{0} 28^{\prime} 7^{\prime \prime}$ & $1^{0} 57^{\prime} 55^{\prime \prime}$ & $1^{0} 26^{\prime} 15^{\prime \prime}$ & $1^{0} 45^{\prime} 57^{\prime \prime}$ \\
\hline 4 & Kepadatan rata-rata (kend-km) & 695 & 213 & 195 & 217 & 199 \\
\hline
\end{tabular}


Perencanaan jaringan lintas untuk jangka pendek yang direkomendasikan dalam penelitian ini yaitu dengan pengalihan angkutan barang yang masuk ke CBD ke Jalan Air Hitam, Jalan SM Amin dan Jalan Yos Sudarso, sehingga kepadatan lalu lintas di Jalan Sudirman dapat berkurang. Kecepatan rata - rata setiap ruas pada tahun 2020 sebesar 33,69 $\mathrm{km} / \mathrm{jam}$ dan pada tahun 2025 menurun menjadi $31,92 \mathrm{~km} / \mathrm{jam}$ apabila perencanaan jaringan lintas angkutan barang tidak dilakukan.

Berikut adalah perbandingan dari performa jaringan jalan baik tanpa JLAB maupun dengan JLAB dan pembangunan jalan lingkar yang dilakukan pada tahun rencana 2030.

Tabel. 2 Perbandingan Performa Jalan di Kota Pekanbaru 2030

\begin{tabular}{|c|c|c|c|c|c|c|}
\hline \multirow[b]{2}{*}{ No } & \multirow[b]{2}{*}{ Indikator } & \multicolumn{5}{|c|}{ Perbandingan performa jalan } \\
\hline & & $\begin{array}{c}\text { Do } \\
\text { nothing }\end{array}$ & $\begin{array}{c}\text { Do } \\
\text { something } \\
\text { Alternatif } \\
1\end{array}$ & $\begin{array}{c}\text { Do } \\
\text { something } \\
\text { Alternatif } \\
2\end{array}$ & $\begin{array}{c}\text { Do } \\
\text { something } \\
\text { Alternatif } \\
3\end{array}$ & $\begin{array}{c}\text { Do } \\
\text { something } \\
\text { Alternatif } \\
4\end{array}$ \\
\hline 1 & Kecepatan (km/jam) & 29,84 & 39,41 & 40,88 & 40,01 & 43,22 \\
\hline 2 & Volume rata-rata (smp/jam) & 2527,5 & 1047 & 1116,9 & 1072,2 & 1073 \\
\hline 3 & Waktu tempuh rata-rata (jam) & $2^{0} 7^{\prime} 45^{\prime}$ & $1^{0} 29^{\prime} 33^{\prime \prime}$ & $1^{0} 49^{\prime} 28^{\prime \prime}$ & $1^{0} 27^{\prime} 14^{\prime \prime}$ & $1^{0} 43^{\prime} 2^{\prime \prime}$ \\
\hline 4 & Kepadatan rata-rata (kend-km) & 862 & 243 & 255 & 241 & 219 \\
\hline
\end{tabular}

Performa jaringan lebih baik dihasilkan dari semua skenario yang dibuat. Penanganan awal dipergunakan skenario I, sedangkan untuk jangka panjang skenario II dapat meningkatkan performa pada tahun 2030 sesuai yang direncanakan, yaitu pembangunan jalan lingkar di Kota Pekanbaru. Sehingga lalu lintas kendaraan angkutan barang dengan perjalanan eksternaleksternal tidak melalui jalan dalam kota yang bisa membuat antrian kendaraan.

\section{SIMPULAN}

Kesimpulan dari hasil analisa didapat bahwa:

1. Berdasarkan hasil analisis, distribusi perjalanan di Kota Pekanbaru tidak merata (mix traffic), Performa lalu lintas tahun dasar 2020, dapat diketahui bahwa kecepatan kendaraan rata - rata pada jaringan sebesar 33,43 km/jam dengan volume rata-rata kendaraan 2069,9 smp/jam, dengan waktu tempuh rata-rata 1 jam 49 menit 55 detik serta kepadatan rata-rata $605 \mathrm{kend} / \mathrm{jam}$. 
2. Pengukuran performa ruas jalan di Kota Pekanbaru yang dilalui oleh kendaraan angkutan barang menunjukan bahwa ruas Jalan Sudirman dan Jalan Kaharuddin Nasution memiliki VC Ratio diatas 0,8 dengan kategori tingkat pelayanan E.

3. Membuat Jaringan Lintas Angkutan Barang merupakan skenario yang dapat di terapkan untuk peningkatan performa ruas jalan dimana ruas jalan yang dijadikan sebagai rute adalah ruas jalan Air Hitam, ruas jalan Arifin Achmad, ruas jalan Datuk Setia Maharaja, ruas jalan Garuda Sakti, ruas jalan Hang Tuah 9, ruas jalan Hangtuah 10, ruas jalan HangTuah 12, ruas jalan HR Soebrantas, ruas jalan Imam Munandar, ruas jalan Kelapa Sawit - Rawamangun, ruas jalan Kubang Raya, ruas jalan Rawamangun, ruas jalan Siak II, ruas jalan Soekarno-Hatta 4, ruas jalan Soekarno-Hatta 5, Jalan Soekarno-Hatta 6, ruas jalan Yos Sudarso 5, dan ruas jalan Lintas Petapahan - Garuda Sakti.

4. Performa setelah dilakukan skenario jaringan lintas angkutan barang merupakan rute jaringan yang paling optimum yang didasarkan dari hasil pembebanan tahun 2025. Kecepatan menjadi 40,02 km/jam dimana pada kondisi tanpa jaringan lintas 31,92 km/jam dan volume rata-rata kendaraan $936 \mathrm{smp} / \mathrm{jam}$ dengan jaringan lintas angkutan barang dan waktu tempuh rata-rata 1 jam 28 menit 7 detik.

5. Pembebanan perjalanan juga dilakukan pada tahun rencana 2030, didapatkan hasil bahwa performa ruas jalan yang paling optimum adalah skenario setelah dilakukan perencanaa jaringan lintas angkutan barang dengan kecepatan yang lebih tinggi dengan kondisi eksisting pada tahun 2030 yaitu 39,41 km/ jam dan volume rata-rata kendaraan $1047 \mathrm{smp} /$ jam dan waktu tempuh rata-rata 1 jam 29 menit 33 detik.

6. Berdasarkan hasil analisis diketahui bahwa terjadi peningkatan performa jalan baik ditahun 2025 dengan ditetapkan jaringan lintas angkutan barang dan ditahun 2030 dengan jaringan lintas angkutan barang.

\section{UCAPAN TERIMA KASIH}

Terima kasih saya sampaikan kepada Prodi Teknik Sipil Universitas Abdurrab dan semua yang membantu serta bekerjasama dalam penelitian ini

\section{DAFTAR PUSTAKA}

[1] Direktorat Jendral Bina Marga Indonesia-Departemen Pekerjaan Umum. 1997. Manual Kapasitas Jalan Indonesia, Jakarta.

[2] Harinaldi. 2005. Prinsip-Prinsip Statistik Untuk Teknik dan Sains, Erlangga, Jakarta 
Rahmat Tisnawan, Fitra Ramdhani, Muhammad Rifky Ariansyaf/ Jurnal Rab Contruction Research 6 (2) (2021)

Prayogo, P. Agung. 2016. Perencanaan Jaringan Lintas Angkutan Barang di Kota Mataram, Bekasi

[3] Pusparini, A. Sanda. 2016. Penataan Lalu Lintas Angkutan Barang di Kota Banjarbaru, Bekasi.

[4] Sugiyono. 2012. Metode Penelitian Kuantitatif Kualitatif dan R\&B. Bandung: Alfabeta.

Tamin, O.Z. 1997. Perencanaan dan Permodelan Transportasi Edisi 1. Bandung : Penerbit ITB Bandung.

[5] Tamin, OZ., 2008. Perencanaan,Pemodelan, \& Rekayasa Transportasi:Teori, Contoh Soal. Penerbit ITB Bandung. 